Joachim Osiński

Bogusław Pytlik

Warsaw School of Economics

\title{
The 2014 European Parliamentary Election in Poland: The Evaluation of the Challenges to the European Union
}

\begin{abstract}
The paper addresses the issue of the election to the European Parliament in Poland. The authors discuss the electoral regulations and the institutional background to the election. They put the 2014 election against the historic background of the 2004 and 2009 elections to the European Parliament. The authors emphasise that the most important challenge in terms of the elections is the low turnout. The major reasons for the state of affairs are the low quality of the knowledge of the European institutions and the social discontent of the Polish citizens with the economic and political situation both in Europe and Poland.
\end{abstract} Keywords: the European Parliament, Election, the European Union, Electoral Regulations

\section{The General Characteristics of the European Parliament}

Taking into consideration the extent of institutionalisation and the formal elements of the process of the broadly understood European integration one should state that the activity of the European institution of parliamentary character was launched on July 23, 1952, after the Treaty of Paris - establishing the European Coal and Steel Community - it came into force. The Treaty represented the basis of the establishment of the Common Assembly, including 78 representatives designated by the parliaments of the Community's member states: France, Western Germany, Belgium, Holland, Luxembourg, and Italy. After the Rome Treaties (establishing the European Economic Community and the European Atomic Community) came into force on January 1, 1958, the European Parliamentary Assembly came into existence. It included 142 MPs. On March 1962 the institution was renamed to the European 
Parliament, which was later confirmed in the Single European Act, signed on February 17, 1986, in Luxembourg and on February 28, 1986 in Hague ${ }^{1}$. Since November 1, 1993, the European Parliament is an institution of the European Union. After the 2014 election it is composed of 751 MPs.

The evolution of the European parliamentary institution, apart from the change in the name and of the number of MPs, included the change in the position and the role of this institution first within the European Communities and later within the European Union structure. From the time perspective one should note that while initially the Assembly was just a consultative body of advisory character, the contemporary European Parliament, while cooperating with the Council of the European Union, may make decisions in many areas of European policies. The European Parliament is consulted in the case of all legal acts initiated by the European Commission. It also oversees other European Union institutions, including the European Commission - it has the power to accept the candidates for the Commission Members. The Parliament also has the power to dismiss the European Commission through a vote of censure.

While taking into consideration the elaborate internal structure of the one Chamber Parliament one should notice that it includes four kinds of bodies: leadership - including the President of the European Parliament, the Parliament's Bureau (the President, 14 Vice-Presidents and 5 Questors ${ }^{2}$ ), the Conference of Presidents (the President, 14 Vice-Presidents and the Representatives of all political factions active in the Parliament as well as 2 representatives of non-attached Members), the Conference of the Heads of the Parliamentary Commissions (both permanent and temporary), Conference of the Heads of Delegations ${ }^{3}$ and the College of Quaestors ${ }^{4}$; meritocratic - the commissions (permanent ${ }^{5}$, investigatory, temporar $y^{6}$ ), inter-parliamentary delegations (established to develop relations with the non-EU parliaments of the countries not aspiring to join the E.U. as well as joint parliamentary commissions with the parliaments of candidate countries or of the countries associated with

1 The Single European Act entered into force on July 1, 1987. It was updating the Treaties of Rome. Its goal was to invigorate the integration process. It also amended some of the European institutions and broadened the European Communities' competencies, for example in the field of the Common Foreign and Security Policy.

2 Their term is 2.5 years, which means that they are elected at the beginning and in the middle of the Parliament's term.

3 It includes all the presidents of the permanent inter-parliamentary delegations. Their main aim is to present the recommendations concerning the delegations' proceedings.

4 The Quaestors are responsible for administrative and financial issues directly concerning the MPs. Their decisions are based on the agreements reached by the Conference of Presidents of the European Parliament.

5 In the present term of the European Parliament there are 20 permanent commissions. The Foreign Affairs Commission includes 2 sub-commissions.

6 The investigatory and temporary commissions may not work longer than 12 months. 
the E.U.); political - political groups numbering at least $25 \mathrm{MPs}$ representing at least $1 / 4$ of the member states ${ }^{7}$; and administrative - the Secretariat General (12 Directors General) and the assisting personnel [Doliwa-Klepacka, Doliwa-Klepacki, 2009, pp. 182-185; Domagała, 2010, pp. 14-23].

The European Parliament could be perceived as a unique phenomenon mostly because it is the only super-national assembly elected in direct popular elections in the World. There are also several important differences between it and the national parliaments of E.U. member states. These include first and foremost: the European Parliament is not the major law-making body of the E.U. - the priority is given to the Council of the European Union and the European Commission, it does not form a government, it does not have a legislative initiative (as this belongs solemnly to the European Commission while the European Parliament and the Council of the European Union may only suggest taking certain legal steps), it may not make decisions concerning its own law-making competencies - as their definition belongs to the member states which determine it via the Council of the European Union.

The general division of the functions of the European Parliament into legislative, budget, control, and creation ones only partly allows it to decide about the issues related to these dimensions of the E.U. activity. Taking into consideration the position of the European Parliament one should state that it is only an assistant institution supporting the E.U. law-making process, which in practice translates into its secondary importance. As far as its participation in the budget-making process is concerned, one should note the advance of its prominence, though. Although the European Parliament must cooperate with the European Commission and the Council of the European Union in that matter, it has the power to amend the "non-obligatory" spending regulations ${ }^{8}$, it may propose obligatory spending and even veto the whole budget and demand establishing a new one. The majority of the control instruments in possession of the European Parliament refer to the European Commission. Apart from the above mentioned right to the vote of no-confidence the European Parliament also votes its approval, MPs may ask the Commission or the Council of the European Union questions (orally or in writing). The Parliament may receive petitions from the citizens of the European Union (natural and legal persons living or having the registered office within the territory of the E.U. member state $)^{9}$. As far as the creative

7 These are: the European People's Party, the Progressive Alliance of Socialists and Democrats, the European Conservatives and Reformists, the Alliance of Liberals and Democrats for Europe Group, the European United Left/Nordic Green Left, the Greens/European Free Alliance, the Europe of Freedom and Direct Democracy.

8 These include spending on regional, social, environmental, and energy policies.

9 Petitions may concern problems directly involving the E.U. 
functions are concerned, the European Parliament has the exclusive right to nominate the Ombudsman. As far as the President and the members of the European Commission are concerned, the Parliament accepts the candidates for these posts. One should add that the European Parliament's participation in the consulting process concerning the nominations for members of the European Court of Auditors and the Board of Directors of the European Central Bank is obligatory.

The development of the parliamentary institution at the beginning of the 1950s may be perceived as an emanation of the aspirations to increase the scope of democratic control over the law-making capacity of the European Communities, especially in the context of the ongoing development of the European integration [Jacobs, Corbett, Shackleton, 1992, p. 32]. As the time goes by, if one compares the European Parliament's evolution with other European institutions one should note that its competencies did not broaden enough to significantly challenge the deficit of democratic legitimacy within the E.U., though. One should also emphasise that this problem does not only refer to the European Parliament but it also concerns the broadly understood democratisation of the E.U. decision-making procedures in general.

Regardless of the fact that the above question is still of central importance as far as the challenges that European Union is facing today are concerned, for a long time there has been no doubt about the democratic legitimacy of the European Parliament. Since June 1979, when the first popular elections to the European Parliament took place, it has enjoyed the position of the only E.U. institution exercising full democratic legitimacy.

\section{The European Parliament: Electoral Regulations in Poland}

In the beginning one should emphasise that in the first place the regulations stipulated in the Treaty of Paris gave the opportunity for an organisation of the popular election to the Assembly according to the individual procedures existing within each member state ${ }^{10}$. The Treaties of Rome include a regulation stipulating that the European Parliamentary Assembly will be formed on the basis of a unanimous procedure in all the member states in the future ${ }^{11}$. Until the introduction of the

10 Article 21, the Treaty establishing the European Coal and Steel Community, http://eur-lex.europa. eu/legal-content/PL/TXT/?uri=CELEX:11951K/TXT (24.01.2015).

${ }_{11}$ Article 108, the Treaty Establishing the European Atomic Energy Community, http://eur-lex.europa. eu/legal-content/EN/TXT/PDF/?uri=CELEX:11957A/TXT\&from=PL (24.01.2015) and Article 138, 
common electoral regulations, the members of the European Parliamentary Assembly were to be chosen by the national parliaments.

The task of drafting the project of electoral regulations introducing popular elections was given to the Assembly. It turned out to be time consuming. It took over 20 years. On September 20, 1976, an Act Concerning the Election of the Representatives of the Assembly by Direct Universal Suffrage was introduced ${ }^{12}$. Following a long ratification procedure it came into force on July 1, 1978. The first popular and direct elections to the European Parliament took place between June 7 and 10, 1979.

The Act Concerning the Election of the Representatives of the Assembly by Direct Universal Suffrage apart from popular and direct elections established the following: the number of MPs elected by each individual member state, a five-year parliamentary term, which allowed to combine the seat in the European Parliament with the seat in the national one ${ }^{13}$, it enumerated a number of posts that could not be combined with the seat in the European Parliament, it introduced regulations concerning premature vacation of the seat and the rules concerning the division of the seats between the member states as well as the timeframe for the elections and the publication of the elections' results. What is particularly important, until establishing the unanimous electoral procedure for all the member states, the elections in each member state were to be conducted according to the electoral regulations binding within this state [Glajcar, 2010, p. 52].

Beginning with 1979, several initiatives were undertaken to develop a unanimous electoral system for all the member states. None of them was successful, though. One may assume that as the number of the E.U. member states was growing, the chances to develop a unanimous electoral regulation were decreasing. An analysis of the problem shows how difficult it is to satisfy the interests of different member states in that matter. On the basis of the European legal regulations it was only possible to define the most general aspects of the elections. More specific problems, such as: the electoral system, the vote counting methods, the number of electoral districts in various states, the different electoral thresholds or the differences concerning the voters' rights are all subject to regulation under the legal systems of the respective E.U. member states [Herbut, 2006, p. 326].

In Poland, between 2004 and 2011, the legal act of central importance for the organisation of the European Parliamentary election was the Ordynacja wyborcza

the Treaty Establishing the European Economic Community, http://eur-lex.europa.eu/legal-content/ PL/TXT/?uri=CELEX:11957E/TXT (24.01.2015).

12 The Act Concerning the Election of the Representatives of the Assembly by Direct Universal Suffrage, http://eur-lex.europa.eu/legal-content/EN/TXT/?uri=CELEX:41976D0787 (25.01.2015).

13 The member states could have limited the regulations concerning the matter. 
do Parlamentu Europejskiego (the European Parliamentary Election Regulation), introduced on January 23, 2004 [JLRP, 2004, item 219]. On January 5, 2011, the regulation was replaced with Kodeks Wyborczy (the Electoral Code) [JLRP, 2011, item 112]. Part VI of this act concerns the elections to the European Parliament.

All the elections in Poland take place during a day off, which in practice means they are held on Sunday or during the whole weekend - if the institution calling the elections decides to do so. In the case of the European Parliament the election must take place within the time period stipulated in the E.U. regulations, and the institution responsible to call the election is the President. All the Polish citizens aged over 18 and all the E.U. citizens who are not Polish but have a permanent residence in Poland and were not forbidden by their home countries to participate in the European Parliamentary elections are eligible to cast votes. All the voters have to be registered. All the citizens who are over 21 and live in Poland or have lived in another E.U. member state for at least 5 years are eligible to run in the elections. The candidates cannot be convicted of a publicly prosecuted crime. Also, foreigners who were forbidden by their home country to run in the elections cannot do so in Poland.

As far as the elections to the European Parliament go, the Polish territory is divided into 13 electoral districts ${ }^{14}$. Seven of them comprise a single voivodship, four of them comprise two voivodships. The remaining two districts encompass the different parts of the Mazowieckie voivodship (including the capital city - Warsaw). The candidates are registered by the electoral committees representing political parties, political parties' coalitions or voters. They do so by presenting lists of candidates signed by at least 10,000 voters permanently residing within a given electoral district.

While taking into account the electoral rights of the Polish voters, with their votes they support a chosen candidate whose name is on the list presented by an electoral committee. Thus, the electoral committee decides who is on the list and in which place on the list. One should add that the candidates in the first place of the list traditionally enjoy the most support. The fact is most often interpreted as an approval of the proposition presented by the electoral committee. It is also important to address the issue of the electoral thresholds. On the country level the threshold is defined at $5 \%$ (the maximum number accepted within the E.U.) [EURATOM, 2002]. The election to the European Parliament is proportional, popular, direct, all votes are equal, and the ballot is secret.

The results of the European Parliamentary election are calculated in two stages.

14 The presented division was proposed in the draft of the electoral law in June 2003. There were also propositions to introduce 7 electoral districts (put forward by Civic Platform) and only 1 electoral district (by the Catholic-National Movement (Ruch Katolicko-Narodowy and the Movement for the Reconstruction of Poland (Ruch Odbudowy Polski)). 
First, at the state level, 51 seats are divided between all the electoral committees which have passed the $5 \%$ electoral threshold. The number of votes won by the district lists of a given committee is the basis for the above calculation. The algorithm used is the same as in the case of the Polish Parliament: the d'Hondt Method (it favours electoral committees with a higher number of votes). It bases on a division of the number of votes gained by the committees participating in the election by consecutive natural numbers equalling the number of seats at the country level. Each committee gets the number of seats which equals the highest quotients out of the 51 available to win [JLRP, 2011, Article 356, item 112].

Second, it is established which candidates in which districts get the seats in the European Parliament. This procedure is based on the Harea-Niemeyer algorithm. The number of votes for each electoral committee is divided by the quota representing the number of votes required for a seat (the total number of votes cast divided by the number of seats). The result for each committee will usually consist of an integer part plus a fractional remainder. Each party is first allocated a number of seats equal to the respective integer. This will generally leave some seats unallocated. The parties are then ranked on the basis of the fractional remainders, and the parties with the largest remainders are each allocated one additional seat until all the seats have been allocated [JLRP, 2011, Article 358, §2-3 and Article 233].

Announcing the official results of the election is at the discretion of the State Electoral Commission, which publicly announces the results and publishes them in Dziennik Ustaw Rzeczypospolitej Polskiej (Journal of Laws of the Republic of Poland). The Commission also prepares an electoral report for the President, the Speaker of the Sejm and the Supreme Court of Poland. The Commission is also obliged to deliver the confirmation of election to all the elected MPs within 14 days after the election. It should also be added that the Speaker of the Sejm immediately after the announcement of the results of the elections informs the President of the European Parliament about the results and provides him or her with the other required documents.

The European Parliament's electoral system in Poland may be perceived as unclear by the voters who do not understand the electoral nuances. One should ask whether or not it was possible to introduce more clear electoral mechanisms. As far as the major Polish political parties are concerned, it seems they are not interested in introducing any changes to the existing procedures. From today's perspective a reform at the European level also seems unlikely. One may mention the proceedings of the Constitutional Commission of the European Parliament. Presented on April 2011, they included several solutions and recommendations to be introduced before the 2014 election [EP, 2011]. The propositions, fundamentally changing the 
state legal regulations, were debated on July 7, 2011, in the European Parliament, which eventually decided to send the report back to the Commission for further consideration. As the European Parliamentary elections in 2014 were run according to the regulations introduced earlier, any standardisation of the electoral procedures seems improbable. One could also ask whether or not it is necessary at all. It seems that a far more important challenge to face is to increase the turnout rate in the elections as well as to strengthen the position of the European Parliament within the E.U. institutional system.

\section{The 2004 and 2009 European Parliamentary Elections in Poland}

Before discussing the 2004 and 2009 European Parliamentary Elections in Poland it should be reminded that on June 7 and 8,2003, Poland ratified in a referendum the Treaty of the Polish Accession to the European Union (the so-called the Accession Referendum). The turnout rate stood at 58.85\% (17 586215 people out of 29868474 legally allowed to vote), $77.45 \%$ of the ones (13 516 612) voted for joining the E.U. [JLRP, 2003]. According to the polls, as far as the access to the E.U. was concerned, the Poles valued the freedom of movement, access to the labour market as well as the issues concerning the environment protection the most. However, they were also afraid of the rising prices, especially of food products. Joining the E.U. enjoyed the highest support of the better educated, interested in politics residents of cities with a stable financial situation [OBOP, 2003].

The preparations to hold the first European Parliamentary Elections in Poland started in April 2004. According to the then regulations, the State Electoral Commission registered 21 electoral committees (14 were registered in all electoral districts). Despite the high number of participants in the elections, the polls suggested that only Civic Platform (Platforma Obywatelska, PO), Self-Defence (Samoobrona RP), the Democratic Left Alliance - Labour United (Sojusz Lewicy Demokratycznej - Unia Pracy, SLD-UP), Law and Justice (Prawo i Sprawedliwość, PiS), the League of Polish Families (Liga Polskich Rodzin, LPR), the Social Democracy of Poland (Socjaldemokracja Polska), the Polish People's Party (Polskie Stronnictwa Ludowe, PSL) and the Freedom Union (Unia Wolności, UW) had a chance to cross the 5\% electoral threshold. The other participants were represented by the electoral committees of the Polish Labour Party (Polska Partia Pracy, PPP), the Real Politics Union (Unia Polityki Realnej, UPR), the Initiative for Poland (Inicjatywa dla Polski, IdP), the Polish Civic Coalition OKO (Ogólnopolski Komitet Obywatelski OKO, OKO), the National Party 
of the Retirees and Pensioners and People's Democratic Party (Krajowa Partia Emerytów i Rencistów i Partia Ludowo-Demokratyczna, KPEiR-PLD), the Anticlerical Party of Progress REASON (Antyklerykalna Partia Postępu "Racja", APP), the Polish National Party (Polska Partia Narodowa, PPN), the Confederation of the Movement to Protect the Unemployed (Konfederacja Ruchu Obrony Bezrobotnych, KROB), the Green Party (Zieloni 2004), the National Rebirth of Poland (Narodowe Odrodzenie Polski, NOP), the Democratic Party of the Left (Demokratyczna Partia Lewicy, DPL), Together for the Future (Razem dla Przyszłości, RdP), and the National Electoral Committee of Voters (NKWW).

For the majority of the Polish political parties the election to the European Parliament turned out not to be their first priority. The ongoing governmental crisis and the preparations for the upcoming national parliamentary elections turned out to be far more important. What is not less important, though, is the fact that the mass media approached the European Parliamentary elections the same way. According to experts, the electoral campaign did not meet the educational expectations. The opportunity to inform the Poles about the role of the European Parliament and other E.U. institutions was missed. The campaign also did not address the issues debated in other E.U. countries such as: the war in Iraq, the debate on Turkey's accession to the E.U., the challenges concerning migration or the potential enlargement of the Eurozone [Czaplicki, 2004]. In practice the local issues concerning regional affairs, the E.U. budget and structural funds (larger support for agriculture - PSL, structural funds - SLD-UP, PO, SDPL, R\&D spending - SDPL, UW), the accession negotiations (SLD-UP reiterated that Poland had negotiated the best conditions possible, Samoobrona RP, LPR, UPR, PPP, KPEiR-PLD and other political parties had an opinion that Poland became the "second tier E.U. country"), the broadly understood patriotic issues, securing long-run economic growth (SLD-UP, SDPL, PO, and UW), agriculture problems (PSL) as well as the Constitutional Treaty (PiS opted for the solutions approved in Nice, LPR and UPR were absolutely against that) came to the fore [Czaplicki, 2004, pp. 7-8].

The first European Parliamentary elections took place on June 13, 2004, just around a month and a half after Poland had joined the E.U. The turnout was low $-20.87 \%{ }^{15}$ (while it stood at $45.47 \%$ within the E.U.). One should mention that the elections do not enjoy a high turnout rate, from 1979 to 2009 the turnout rate was decreasing. The reasons for this trend include: the dominant narrative of state-related issues in the campaigns, the disappointing engagement on the part of the mass media in promoting the elections, the lack of information concerning the European

15 The turnout was lower only in Slovakia - $16.97 \%$. 
Parliament and the insufficient knowledge of the electoral law. Both in Poland and in other E.U. countries, the elections play a secondary role to the national parliamentary elections, presidential elections, or even elections to local self-governments. In the case of Poland the reasons for the low turnout include apathy caused by the ongoing political developments, the lack of vested interests in politics or the opinions that the elections are just an opportunity for politicians to win well-paid positions [Cybulska, 2004, pp. 8-9].

Table 1. The Results of the 2004 European Parliamentary Election in Poland

\begin{tabular}{|c|l|c|c|c|}
\hline No. & \multicolumn{1}{|c|}{ Electoral Committee } & Support \% & $\begin{array}{c}\text { Number } \\
\text { of Votes }\end{array}$ & $\begin{array}{c}\text { Number } \\
\text { of Seats }\end{array}$ \\
\hline 1 & Civic Platform (Platforma Obywatelska, PO) & 24.10 & 1467775 & 15 \\
\hline 2 & the League of Polish Families (Liga Polskich Rodzin, LPR) & 15.92 & 969869 & 10 \\
\hline 3 & Law and Justice (Prawo i Sprawedliwość, PiS) & 12.67 & 771858 & 7 \\
\hline 4 & Self-Defence (Samoobrona RP) & 10.78 & 656782 & 6 \\
\hline 5 & $\begin{array}{l}\text { the Democratic Left Alliance - Labour United (Sojusz Lewicy } \\
\text { Demokratycznej - Unia Pracy, SLD-UP) }\end{array}$ & 9.35 & 569311 & 5 \\
\hline 6 & the Freedom Union (Unia Wolności, UW) & 7.33 & 446549 & 4 \\
\hline 7 & the Polish People's Party (Polskie Stronnictwo Ludowe, PSL) & 6.34 & 386340 & 4 \\
\hline 8 & the Social Democracy of Poland (Socjaldemokracja Polska) & 5.33 & 324707 & 3 \\
\hline 9 & the Real Politics Union (Unia Polityki Realnej, UPR) & 1.87 & 113675 & - \\
\hline 10 & the National Electoral Committee of Voters (NKWW) & 1.56 & 94867 & - \\
\hline 11 & the Initiative for Poland (Inicjatywa dla Polski, IdP) & 1.45 & 88565 & - \\
\hline 12 & $\begin{array}{l}\text { the National Party of the Retirees and Pensioners and People's } \\
\text { Democratic Party (Krajowa Partia Emerytów i Rencistów i Partia } \\
\text { Ludowo-Demokratyczna, KPEiR-PLD) }\end{array}$ & 0.80 & 46667 & - \\
\hline 13 & $\begin{array}{l}\text { the Confederation of the Movement to Protect the Unemployed } \\
\text { (Konfederacja Ruchu Obrony Bezrobotnych, KROB) }\end{array}$ & 0.61 & 36937 & - \\
\hline 14 & $\begin{array}{l}\text { the Polish Civic Coalition OKO (Ogólnopolski Komitet Obywatelski } \\
\text { OKO, OKO) }\end{array}$ & 0.58 & 35180 & - \\
\hline 15 & the Polish Labour Party (Polska Partia Pracy, PPP) & 0.54 & 32807 & - \\
\hline 16 & $\begin{array}{l}\text { the Anticlerical Party of Progress REASON (Antyklerykalna Partia } \\
\text { Postępu “Racja”, APP) }\end{array}$ & 0.30 & 18068 & - \\
\hline 17 & the Green Party (Zieloni 2004) & 0.27 & 16288 & - \\
\hline 18 & $\begin{array}{l}\text { the Democratic Party of the Left (Demokratyczna Partia Lewicy, } \\
\text { DPL) }\end{array}$ & 0.09 & 5513 & - \\
\hline 19 & Together for the Future (Razem dla Przyszłości, RdP) & 0.05 & 2897 & - \\
\hline 20 & the National Rebirth of Poland (Narodowe Odrodzenie Polski, NOP) & 0.04 & 2546 & - \\
\hline 21 & the Polish National Party (Polska Partia Narodowa, PPN) & 0.04 & 2510 & - \\
\hline Total & \multicolumn{1}{|c|}{ - } & 4621936 & 54 \\
\hline
\end{tabular}

Source: SEC [2004]. 
Eventually, the elections were won by Civic Platform (24\% of the total votes cast). The party won in 8 out of the 13 electoral districts. The League of Polish Families also did well, despite the fact that it launched an anti-E.U. campaign (16\%). The growing popularity of Law and Justice was reflected in the winning of $13 \%$ of the total votes cast and being in the third place. It is hard to interpret the $11 \%$ won by Self-Defence (Samoobrona) as a success, though. According to the polls of March 2004, the party had a chance to win $30 \%$ of the total votes cast. SLD-UP won $9 \%$ of the total votes cast, based on the stable left-wing electorate. The only party that was not represented in the Sejm that won seats in the European Parliament was the Freedom Union, with $7 \%$ of the total votes cast. It is important to note that the party had a similar profile to Civic Platform. The results of the Polish People's Party, i.e. 6\%, was interpreted as a signal of scepticism of the Polish farmers concerning the European Union and of the expectations of the subsidies allocated under the Common Agricultural Policy (CAP). The Social Democracy of Poland, with the 5\% support, did worse than the PSL. However, taking into consideration the fact of the lack of regional structures in place, inadequate financial support and not well-recognised candidates, the party's performance was generally viewed as positive.

Taking into consideration the significance of the 2004 European Parliamentary election in Poland to the Polish political landscape one may state that it opened up the period of the deconstruction of the bipolar political rivalry between the parties of the post-Solidarity and post-Communist descent. The observation was confirmed by the following national parliamentary election. The parties that celebrated the biggest electoral success and participated the most in exercising power were the post-Solidarity Civic Platform and Law and Justice. Following the 2004 election, the Polish political parties system is divided into the parties that initiate and supplement cooperation at the government level. Furthermore, following the 2004 election, the dynamics of change in the approval ratings diminished significantly. Finally, the electoral chances of non-parliamentary political parties have also diminished [Wojtasik, 2010, p. 76].

From a different perspective, following the 2004 election, the Polish EMPs in the European Parliament joined various political groups. The representatives of Civic Platform and of the Polish People's Party joined the European People's Party Group - European Democrats (EPP-ED), the representatives of the Democratic Left Alliance - Labour United and the Social Democracy of Poland - the European Socialists Party Group (PES), the Freedom Union - The Alliance of Liberals and Democrats for Europe Group (ALDE/ADLE), Law and Justice - the Union for a Europe of the Nations Group (UEN). The majority of the League of Polish Families MPs also joined the latter. The rest of the LPR EMPs joined the Independence/Democracy Group (IND/DEM). The majority of the representatives of Self-Defence (Samoobrona RP) 
joined Independence/Democracy Group (IND/DEM), the remaining ones joined the European Socialists Party Group (PES) or the Alliance of Liberals and Democrats for Europe Group (ALDE/ADLE).

The next election to the European Parliament in Poland was held on June 7, 2009. This time, Poland was assigned 50 instead of 54 seats. The change was based on the content of the Treaty of Nice. The earlier number was a result of the fact that Romania and Bulgaria signed the Accession Treaties on April 20, 2005 ${ }^{16}$. Thus, the countries that joined the E.U. in 2004 temporarily earned more seats in the European Parliament.

On April 28, 2009, the State Electoral Commission registered 12 electoral committees, 10 of which were registered in all electoral districts. According to the polls, the committees of Civic Platform, Law and Justice, and the Democratic Left Alliance - Labour United had the biggest chances to cross the electoral threshold. It is worth noting that following the elections to the Polish Sejm on October 21, 2007, a crystallised group of four strong parties was established (PO, PiS, PSL, and SLD), while other parties were subject to marginalisation (they were not even nearing the threshold in the polls). The other participants in the 2009 European Parliamentary election in Poland were represented by the electoral committees of the Real Politics Union, Self-Defence (Samoobrona RP), the Polish Labour Party, the Libertas Polska (LP) ${ }^{17}$, the Alliance for the Future (Porozumienie dla Przyszłości - Centrolewica, PdP) ${ }^{18}$, the Right Wing of the Republic (Prawica Rzeczypospolitej, PR), the Polish Socialist Party (Polska Partia Socjalistyczna, PPS) and Go Forward Poland (Naprzód Polsko - Piast, NPP).

Similar to the 2004 campaign, the electoral campaign as far as the expected benefits were concerned, was mostly of local character. While in the other E.U. countries the narrative that was prevalent in the campaign included counteracting the 2008+ financial crisis consequences, boosting economic growth, fighting unemployment and inflation, the narrative that prevailed in the Polish campaign covered i.a. the effective spending of the E.U. funds, fighting protectionism and isolationism (PO), energy security (PO, PSL, SLD-UP), the development of agricultural areas (PiS, PSL), supporting farmers (PSL, LP), fighting unemployment and protecting jobs (PiS, PdP, LP), sustainable development (SLD, PdP), opposing the Treaty of Lisbon (LP, UPR), or introducing the Euro in Poland (PR).

16 The Treaty, because of the place of its signature called the Treaty of Luxemburg, entered into force on January 1, 2007.

${ }^{17}$ In 2009 the party was represented by the candidates connected with the League of Polish Families, the Party of Regions (Partia Regionów, PR), The Christian National Union (Zjednoczenie ChrześcijańskoNarodowe, $\mathrm{ZChN}$ ) and the Organisation of the Polish Nation - Polish League (Organizacja Narodu Polskiego - Liga Polska, ONP-LP).

18 The electoral committee included the Democratic Party (Partia Demokratyczna, PD), the Social Democracy of Poland (Socjaldemokracja Polska) and the Green Party 2004 (Zieloni 2004). 
From the Polish local perspective, the spring of 2009 was the time of the evaluation of the efficacy of Donald Tusk's PO-PSL government by both major political parties: $\mathrm{PO}$ and PiS. In the meantime PSL and SLD were trying to preserve their positions as potential coalition partners. While analysing the 2009 political campaign one may state that PO and PSL were fighting to sustain the status quo - the dominant ruling party as for PO, not standing to lose what it had for PSL. The goal of PiS and SLD was to reverse the disadvantageous trend and win more support of the voters. The parties that were not present in the Parliament were focused on winning seats and gaining access to the mainstream of the Polish politics [Wojtasik, 2010, p. 79]. While taking the above observations into account, the electoral campaign concerning the European Parliamentary election preceded the presidential and local self-government elections of 2010 and the parliamentary ones of 2011. Thus the mass media were more interested in the growing tension between the Prime Minister and the President. However, there was still ground to state that the 2009 European Parliamentary electoral campaign was more significant than the one of 2004. The Internet played a decisive role in that respect.

The turnout on June 27, 2009, was a bit higher than in the case of the 2004 election - $24.53 \%{ }^{19}$ (43\% within the E.U.). According to the polls men had cast more votes than women. The group which participated the most, represented the residents of big and medium-sized towns, holding a university degree, between 45 and 54 years of age. The Poles of the right-wing affiliation cast votes in higher numbers than the representatives of other political affiliations. As far as party supporters were concerned, the supporters of PO and PIS were in the majority. The supporters of PSL and SLD-UP cast almost the same number of votes. Moreover, most of the voters were pro-E.U. membership oriented [CBOS, 2009, p. 5]. Generally it is assumed that the low turnout was a negative reaction to the political rivalry between the major political players, the unfamiliarity with the candidates, the negative evaluation of the electoral campaign as well as the political manifestos of the political parties, the lack of the knowledge of the European Parliament, the disappointing forms of communication on the part of the politicians with the voters [CBOS, 2009, p. 11].

Eventually, the results of the June 7, 2009 election confirmed the support of the ruling Civic Platform. The party won $44.43 \%$ of the total votes cast, which translated into 25 seats in the European Parliament and it meant the party won in 9 electoral districts. Law and Justice also noted a relatively high support: $27.40 \%$ of the total votes cast, 15 seats and victory in 4 electoral districts. The electoral committee of SLD - UP won $12.34 \%$ of the total votes cast. This meant 7 seats in the European

19 The turnout was lower than in Poland only in Lithuania (20.98\%) and Slovakia (19.64\%). 
Parliament. All the parties posted significantly better electoral results compared to the 2004 figures. The electoral result of the Polish People's Party, i.e. 7.01\% of the total votes cast, also marked an upward trend, despite the fact that it did not translate into a higher number of seats.

Table 2. The Results of the 2009 European Parliamentary Election in Poland

\begin{tabular}{|c|l|c|c|c|}
\hline No. & \multicolumn{1}{|c|}{ Electoral Committee } & Support \% & $\begin{array}{c}\text { Number } \\
\text { of Votes }\end{array}$ & $\begin{array}{c}\text { Number } \\
\text { of Seats }\end{array}$ \\
\hline 1 & Civic Platform (Platforma Obywatelska, P0) & 44.43 & 3271852 & 25 \\
\hline 2 & Law and Justice (Prawo i Sprawedliwość, PiS) & 27.40 & 2017607 & 15 \\
\hline 3 & $\begin{array}{l}\text { the Democratic Left Alliance - Labour United (Sojusz Lewicy } \\
\text { Demokratycznej - Unia Pracy, SLD-UP) }\end{array}$ & 12.34 & 908765 & 7 \\
\hline 4 & the Polish People's Party (Polskie Stronnictwo Ludowe, PSL) & 7.01 & 516146 & 3 \\
\hline 5 & $\begin{array}{l}\text { the Alliance for the Future (Porozumienie dla Przyszłości } \\
\text { - Centrolewica, PdP) }\end{array}$ & 2.44 & 179602 & - \\
\hline 6 & the Right Wing of the Republic (Prawica Rzeczypospolitej, PR) & 1.95 & 143966 & - \\
\hline 7 & Self-Defence (Samoobrona RP) & 1.46 & 107185 & - \\
\hline 8 & Libertas Polska (LP) & 1.14 & 83754 & - \\
\hline 9 & the Real Politics Union & 1.10 & 81146 & - \\
\hline 10 & the Polish Labour Party & 0.70 & 51872 & - \\
\hline 11 & Go Forward Poland (Naprzód Polsko - Piast, NPP) & 0.02 & 1537 & - \\
\hline 12 & the Polish Socialist Party (Polska Partia Socjalistyczna, PPS) & 0.02 & 1331 & - \\
\hline Total & & & 7364763 & 50 \\
\hline
\end{tabular}

Source: SEC [2009].

The results of the European Parliamentary election did not foretell any significant changes in the Polish political parties system. One should rather say that they confirmed the trends observed following the national parliamentary election of October 21, 2007 relating to the four major political parties. There was also no new party which would win a minimum of $5 \%$ of social support.

From the Polish perspective, the $7^{\text {th }}$ term of the European Parliament (2009-2014) started with an important event. During the first session on July 14, 2009, Jerzy Buzek, the former Prime Minister (1997-2001), the EMP representing the Civic Platform electoral list was elected the President of the European Parliament ${ }^{20}$. The Polish EMPs from this party as well as the representatives of the Polish People's Party again joined the European People's Party Group (EPP). The Law and Justice EMPs joined the European Conservatives and Reformists Group (ECR), the ones elected from the SLD-UP electoral list - the Progressive Alliance of Socialists and Democrats Group

${ }^{20}$ He held the post till January 17, 2009. He was succeeded by M. Schulz. 
(S\&D). One should note that during the term small changes occurred: 4 representatives of PiS moved to the Europe of Freedom and Democracy Group (EFD) and one representative of Civic Platform moved to the ECR.

When the Treaty of Lisbon came into force, the European Parliament added 18 seats (an increase from 736 to 754 ), one of these was assigned to Poland. The extra seat was assigned to the Polish People's Party.

\section{The 2014 European Parliamentary Election}

The election of the representatives of the E.U.-28 to the European Parliament was held between May 22 and 25, 2014, under the decision of the Council of the European Union of June 14, 2013 $3^{21} .751$ seats were contested (15 fewer than in the $7^{\text {th }}$ term). Poland was assigned 51 seats. Formally the new term began on July 1 , 2014. In terms of the conduct of the election, Poland was divided into 13 electoral districts (Table 3).

Table 3. Electoral Districts in the 2014 European Parliamentary Election in Poland

\begin{tabular}{|l|l|l|}
\hline \multicolumn{1}{|c|}{$\begin{array}{c}\text { Number of } \\
\text { Electoral District }\end{array}$} & \multicolumn{1}{|c|}{ Territorial Administrative Unit within the Electoral District } & \multicolumn{1}{c|}{$\begin{array}{c}\text { Electoral District } \\
\text { Commission Location }\end{array}$} \\
\hline District No.1 & the Pomorskie Voivodship & Gdańsk \\
\hline District No. 2 & the Kujawsko-Pomorskie Voivodship & Bydgoszcz \\
\hline District No. 3 & the Podlaskie and Warmińsko-Mazurskie Voivodships & Olsztyn \\
\hline District No. 4 & Warsaw and 8 Counties of the Mazowieckie Voivodship & Warszawa \\
\hline District No. 5 & 4 Townships and 29 Counties of the Mazowieckie Voivodship & Warszawa \\
\hline District No. 6 & the Łódzkie Voivodship & Łódź \\
\hline District No. 7 & the Wielkopolskie Voivodship & Poznań \\
\hline District No. 8 & the Lubelskie Voivodship & Lublin \\
\hline District No. 9 & the Podkarpackie Voivodship & Rzeszów \\
\hline District No. 10 & the Małopolskie and Świętokrzyskie Voivodships & Kraków \\
\hline District No.11 & the Śląskie Voivodship & Katowice \\
\hline District No.12 & the Dolnośląskie and Opolskie Voivodships & Wrocław \\
\hline District No. 13 & the Lubuskie and Zachodnio-Pomorskie Voivodships & Gorzów Wielkopolski \\
\hline
\end{tabular}

Source: JLRP [2004].

21 The elections were held on May 22 (Thursday) in the Netherlands and Great Britain, May 23 (Friday) in Ireland, on May 23 and 24 (Friday and Saturday) in the Czech Republic, on May 24 (Saturday) in Latvia, Malta and Slovakia, May 25 (Sunday) in Austria, Belgium, Bulgaria, Croatia, Cyprus, Denmark, Estonia, Finland, France, Greece, Spain, Lithuania, Luxemburg, Germany, Poland, Portugal, Romania, Slovenia, Sweden, Hungary and Italy. 
The electoral calendar outlined a roadmap of elections. One of its most important elements was April 7,2014 - the deadline for the registration of electoral committees with the State Electoral Commission. These included the committees representing one political party, a coalition of parties or the voters supporting a non-governmental organisation. April 15 (12 p.m.), was the deadline for the registration in a respective electoral district of the lists of candidates to the European Parliament ${ }^{22}$. Registration in at least 7 electoral districts allowed the committee to gain the status of a countrywide committee, which benefited the committee on grounds of the economies of scale. Important in terms of image, less of the benefits involved, was the lottery system of assigning the electoral lists' numbers for the electoral lists registered in at least 2 electoral districts ${ }^{23}$.

During the European Parliamentary Election, similar to all the other election types in Poland, the so-called electoral silence is binding. This means a strict ban of any form of political campaigning or publishing polls referring to the electoral chances of the candidates running in the election ${ }^{24}$. Public disclosure of the polls referring to the electoral behaviour or projected results, including the projected turnout, as well as posting any pieces of information about the candidates or the committees registered in a given electoral district is subject to penalty. Electoral silence is introduced 24 hours before the election day. In 2014 this was May 24, 0.0 a.m. This practice is often debated by constitutional lawyers as well as political science professionals. Nowadays, the Polish language, social media as well as the use of the Internet resources make it difficult to justify the legitimacy of this regulation. However, electoral silence does not prevent the media from reporting on elections, publishing the turnout data compiled in a given electoral district or in Poland as a whole on a given hour of the election day, or from encouraging the voters to cast a vote in the election.

The following electoral committees registered their lists in all the 13 electoral districts:

1. The Electoral Coalition Committee of Europe Plus Your Movement (Koalicyjny Komitet Wyborczy Europa Plus Twój Ruch) - the list also included some representatives of the Democratic Party (Partia Demokratyczna) and of the Alliance of Democrats (Stronnictwo Demokratyczne);

2. The Electoral Coalition Committee of the Democratic Left Alliance - Labour United (Sojusz Lewicy Demokratycznej - Unia Pracy);

${ }^{22}$ For detailed information concerning the registration of candidates in the European Parliamentary Election see: www.pkw.gov.pl (2.03.2014).

${ }^{23}$ For the lottery rules, see: www.pkw.gov.pl. (21.10.2014).

${ }^{24}$ For The State Electoral Commission's explanations concerning the electoral silence see: www.pkw. gov.pl (27.05.2014). 
3. The Electoral Committee of the New Right - under Janusz Korwin Mikke (Nowa Prawica - Janusz Korwin Mikke);

4. The Electoral Committee of Civic Platform - RP (Platforma Obywatelska RP);

5. The Electoral Committee of Poland Together under Jarosław Gowin (Polska Razem Jarosława Gowina);

6. The Electoral Committee of the Polish People's Party (Polskie Stronnictwo Ludowe);

7. The Electoral Committee of Law and Justice (Prawo i Sprawiedliwość) - the list also included some representatives of the Right Wing of the Republic and of the Party "Piast";

8. The Electoral Committee of Solidarity for Poland under Zbigniew Ziobro (Solidarna Polska Zbigniewa Ziobro);

9. The Electoral Committee of Voters for the National Movement - the list also included the representatives of the Real Politics Union;

Compared to the previous elections, the number of the electoral committees having the capacity to register in all the districts was 9 instead of 10.3 committees had the capacity to register only in some electoral districts:

1. The Electoral Committee of Direct Democracy (Demokracja Bezpośrednia), electoral districts No. 1, 3, 6, 8, 10, and 11) - the list included the representatives of the Polish Party of Pirates (Polska Partia Piratów) and of the Libertarian Party (Partia Libertariańska);

2. The Electoral Committee of the Green Party (Partia Zieloni), electoral districts No. 1, 4, 6, 11, and 13 - the list also included the representatives of the Women's Party (Partia Kobiet) and of the Polish Socialist Party (Polska Partia Socjalistyczna); 3. The Electoral Commitee of Self-Defence (Samoobrona) (electoral districts No. 3 and 6).

The remaining 8 committees did not manage to register their electoral lists in any of the electoral districts and their candidates were not eligible to run in the election. These included, for example: the Electoral Committee of Naprawimyto.org (WeWillFixThat.org), the Electoral Committee of the Defenders of the Traditional Luncheon Meats (Komitet Wyborczy Wyborców Obrony Wędlin Tradycyjnych), the Electoral Committee of Voters: the Outraged (Komitet Wyborczy Wyborców Oburzeni), the Electoral Committee of Voters: Freedom (Komitet Wyborczy Wyborców Wolność). Thus, out of the initial 20 committees 12 were registered and ran in the election. According to the lottery numbers, No. 1 went to the Electoral Committee of Solidarity for Poland under Zbigniew Ziobro. The two largest Polish parties: Civic Platform and Law and Justice were assigned No. 8 and No. 4, respectively.

Between March 26 and May 23, 2014, many opinion poll agencies ran polls on the possible election outcomes. According to approval ratings, the winners would 
be either Civic Platform or Law and Justice. The remaining parties were of marginal importance. However, there were electoral districts were the Polish People's Party (electoral district No. 8 - the Lubuskie voivodship) or the Democratic Left Alliance (electoral district No. 2 - the Kujawsko - Pomorskie voivodship) would have been successful. The approval ratings also indicated that the districts in the West, North, and South were the ones where Civic Platform would win by a large margin. The results confirmed the projections, which, in turn, indicates the growing professionalism of the opinion poll agencies, which was not the case in the context of the earlier elections.

The political programmes designed by the political parties and electoral committees did not introduce an element of surprise to the European Parliamentary electoral campaign. They did not differ much from the other elections held in Poland. The issues raised in the campaign addressed the ways of dealing with the 2008+ crisis and improving the economic outlook, especially in terms of the labour market and youth unemployment. The problem of the depreciating Euro against the U.S. Dollar also influenced the debates on joining the eurozone. The ruling parties emphasised the successful absorption of the E.U. funds and the positive impact it had on the construction of roads and transport infrastructure. However, the opposition parties, especially Law and Justice, were pointing to the cases of mismanagement of the E.U. funds as well. Nevertheless, all the Polish EMPs were trying to persuade voters that they would do their best to protect or even expand the scope of the European financial support.

The left-wing candidates addressed the issue of the $27 \mathrm{~m}$ unemployed within the E.U. and the need to give a boost to the economy to create more jobs, especially for the youth. While putting the blame on the financial institutions, especially banks for the economic crisis, they demanded to increase - at both the state and the European level - the control over the financial institutions (the European Banking Union), which would mitigate the future risks of a financial crisis. They built on the outrage against the "too big to fall" institutions which were rescued through taxpayers' money. Thus the left opted for "social Europe" based upon the development of social programmes designed not only at the state but also at the European level [Kandydaci..., n.d.]. The diversity of the E.U. was viewed as an asset, which should be protected along with the civil rights and freedoms/personal liberties acting against any form of discrimination of minorities.

The new element of the 2014 European Parliamentary electoral campaign in Poland as well as in other European countries (Great Britain, France, the Netherlands, Hungary, etc.) was the rise of anti-E.U. political groups questioning the previous E.U. accomplishments. In Poland this trend was represented by the New Right under Janusz Korwin Mikke. The party promised to limit the influence of the E.U. and 
eventually reduce it to the FTA status. The candidates reiterated bizarre E.U. regulations, the bloated E.U. bureaucracy and they promised to prevent similar trends from occurring in the future. They claimed that the Polish government should use its veto power to oppose the development of Brussels' competencies at the expense of the E.U. member states [NP, 2014]. It should be noted that such promises proved to be effective in the context of the electoral campaign and eventually resulted in the political success of the parties promulgating such viewpoints in various E.U. member states, for example in France.

\section{The Evaluation of the 2014 European Parliamentary Election Results in Poland}

The election was held on May 25. It was not interrupted by any kind of electoral incidents which would influence the results. The consecutive statements of the State Electoral Commission indicated that the turnout would not be high, apart from some big cities. The final results showed that the lowest turnout was posted in the Warmińsko-Mazurskie voivodship (17.42\%) whereas the highest in the Mazowieckie voivodship (28.09\%). The average turnout was $23.83 \%$. Compared to the other E.U. member states it should be perceived as very low (Belgium $-89.64 \%$, Luxembourg - $85.55 \%$, Malta $-74.80 \%$, or Greece - 59.97\%). The turnout rate was close to Slovenia $-24.55 \%$, Croatia $-25.24 \%$ or Hungary $-28.97 \%$. The turnout lower than in Poland was posted only in the Czech Republic - 18.20\% and Slovakia - 13.05\%. This means that in terms of the electoral turnout, out of the E.U.-28 member states Poland was in the 26 place [EP, 2014a]. This indicates that the Polish society is barely interested in the procedure, which, according to numerous pieces of research, is largely misunderstood by the majority of the citizens. Part of the society also does not see a direct connection between their economic or social situation and the decisions of the European Parliament. Even some of the candidates had problems with outlining the role of the European Parliament and how it works. Some of them even claimed it has competencies it does not have in reality. Thus, one may state that the low turnout was largely influenced by the lack of the knowledge of the competences and the functioning of the European Parliament, especially in the case of the potential voters countrywide or in small towns [Dudkiewicz et al., 2013; Łada, Fałkowska-Warska, 2012]. The other reason was the emergence of the anti-E.U. parties that openly demonstrated their discontent with the functioning of the E.U. (such as the New Right under Janusz Korwin Mikke) which, apart from moving the public opinion, attracted a lot of media attention. It turned out the media reporting on the campaign were 
more interested in the sound bites rather than in educating the future voters about the E.U. institutions. Finally, the low turnout was also a consequence of perceiving the election in the context of the economic and social situation in Poland by a large part of society. The inability of the ruling coalition to address the issues of the labour market, unemployment, the travails of the various industries, healthcare services or education was subject to dispute as the issues were perceived as more important to the citizens than the European policies which they did not fully understand.

The election results came as a surprise as the ruling Civic Platform won the same number of seats (19) as the biggest opposition party - Law and Justice. The difference between the parties was just around 25000 votes, which marked a small fraction out of the 7 million voters who went to the polls. Eventually, 5 electoral committees won seats in the European Parliament (Table 4). As far as the Electoral Coalition Committee of the Democratic Left Alliance - Labour United is concerned, the two represented parties won seats (the Democratic Left Alliance - 3 seats, Labour United - 1 seat).

Table 4. The Results of the 2014 European Parliamentary Election in Poland

\begin{tabular}{|c|c|c|c|c|c|c|}
\hline \multirow{2}{*}{\multicolumn{2}{|c|}{ Electoral Committee }} & \multicolumn{3}{|c|}{ Votes } & \multicolumn{2}{|c|}{ Seats } \\
\hline & & \multirow{2}{*}{$\begin{array}{c}\text { Number } \\
2271215\end{array}$} & \multirow{2}{*}{$\begin{array}{c}\% \\
32.13\end{array}$} & \multirow{2}{*}{$\begin{array}{c}+/- \\
-12.30\end{array}$} & \multirow{2}{*}{$\begin{array}{c}\text { Number } \\
19 / 51\end{array}$} & \multirow{2}{*}{$\begin{array}{l}+1- \\
-6\end{array}$} \\
\hline No. 4 & Civil Platform - RP (Platforma Obywatelska RP) & & & & & \\
\hline No. 7 & Law and Justice (Prawo i Sprawiedliwość) & 2246870 & 31.78 & +4.38 & $19 / 51$ & +4 \\
\hline No. 2 & $\begin{array}{l}\text { the Democratic Left Alliance - Labour United (Sojusz } \\
\text { Lewicy Demokratycznej - Unia Pracy) }\end{array}$ & 667319 & 9.44 & -2.90 & $\begin{array}{c}5 / 51 \\
(4 / 51) \\
(1 / 51)\end{array}$ & -2 \\
\hline No. 3 & $\begin{array}{l}\text { the New Right - Janusz Korwin Mikke (Nowa Prawica } \\
\text { - Janusz Korwin Mikke) }\end{array}$ & 505586 & 7.15 & - & $4 / 51$ & - \\
\hline No. 6 & the Polish People's Party (Polskie Stronnictwo Ludowe) & 480846 & 6.80 & -0.21 & $4 / 51$ & +1 \\
\hline & $\begin{array}{l}\text { Solidarity for Poland under Zbigniew Ziobro (Solidarna } \\
\text { Polska Zbigniewa Ziobro) }\end{array}$ & 281079 & 3.98 & - & $0 / 51$ & - \\
\hline & $\begin{array}{l}\text { Europe Plus Your Movement (Koalicyjny Komitet } \\
\text { Wyborczy Europa Plus Twój Ruch) }\end{array}$ & 252779 & 3.58 & - & $0 / 51$ & - \\
\hline & $\begin{array}{l}\text { Poland Together under Jarosław Gowin (Polska Razem } \\
\text { Jarosława Gowina) }\end{array}$ & 223733 & 3.16 & - & $0 / 51$ & - \\
\hline & the National Movement (Ruch Narodowy) & 98626 & 1.40 & - & $0 / 51$ & - \\
\hline & the Green Party (Partia Zieloni) & 22481 & 0.32 & - & $0 / 51$ & - \\
\hline & Direct Democracy (Demokracja Bezpośrednia) & 16222 & 0.23 & - & $0 / 51$ & - \\
\hline & Self-Defence (Samoobrona) & 2729 & 0.04 & -1.42 & $0 / 51$ & - \\
\hline Total & & 7069485 & 100.0 & - & $51 / 51$ & - \\
\hline
\end{tabular}

Source: SEC [2014]. 
The 7 committees which did not win any seats together attracted around 900000 votes but did not cross the electoral $5 \%$ threshold. The dominance of the ruling party and of the leading opposition party was not a surprise. However, the 4 seats and 0.5 million votes supporting the New Right was surprising. The anti-E.U. parties won even more seats in France (the National Front $-24.86 \%$, which was the best result in France) or in Great Britain (the U.K. Independence Party - 26.77\% [EP, 2014b]). However, historically none of the similar Polish parties have ever been so successful. In total, there will be around $100 \mathrm{MPs}$ in the European Parliament during its $8^{\text {th }}$ term who will represent their critical approach to the European integration and European institutions. The question is whether or not they can play a decisive role in the functioning of the European Parliament. One should doubt that as they are not grouped within one political group in the European Parliament. They are represented across many groups within the European Parliament, and some of them are non-attached members. Furthermore, the political groups work under democratic procedures, and they are not inherently anti-E.U.-oriented. The number of seats of each political group in the European Parliament is presented in Table 5.

Table 5. Political Groups in the 2014 European Parliament - the Number of Seats and the Percentage of Votes in the Parliament

\begin{tabular}{|c|c|}
\hline The European People's Party (EPP) & $\begin{array}{l}221 \text { seats } \\
29.43 \% \text { of votes }\end{array}$ \\
\hline The Progressive Alliance of Socialists and Democrats (S\&D) & $\begin{array}{l}191 \text { seats } \\
25.43 \% \text { of votes }\end{array}$ \\
\hline The European Conservatives and Reformists (ECR) & $\begin{array}{l}70 \text { seats } \\
9.32 \% \text { of votes }\end{array}$ \\
\hline The Alliance of Liberals and Democrats for Europe Group (ALDE/ADLE) & $\begin{array}{l}67 \text { seats } \\
8.92 \% \text { of votes }\end{array}$ \\
\hline The European United Left/Nordic Green Left (GUE/NGL) & $\begin{array}{l}52 \text { seats } \\
6.92 \% \text { of votes }\end{array}$ \\
\hline The Greens/European Free Alliance (Greens/EFA) & $\begin{array}{l}50 \text { seats } \\
6.66 \% \text { of votes }\end{array}$ \\
\hline The Europe of Freedom and Direct Democracy (EFDD or EFD) & $\begin{array}{l}48 \text { seats } \\
6.39 \% \text { of votes }\end{array}$ \\
\hline Non-Attached Members (NI) - not belonging to any political group & $\begin{array}{l}52 \text { seats } \\
6.92 \% \text { of votes }\end{array}$ \\
\hline
\end{tabular}

Source: EP [2014b].

One may expect that the leaders of the anti-E.U. parties in the different E.U. member states will strive to win popularity as well as the position of the leader of the "the anti-EU opposition", treating this as a tool to win support in the next national parliamentary elections in the states they come from. 


\section{Summary}

To conclude, the 2014 European Parliamentary election in Poland marked a consolidation moment of the Polish electoral system both in theory and in practice. As usual, some complaints about the conduct of the election or the performance of the individual electoral commissions were lodged with the State Electoral Commission and the courts. However, every single time it turned out to be of marginal importance and it had no influence on the results of the election. Gaining experience concerning the electoral procedures marks an important step on the road to develop a stable democracy in Poland. However, one should not forget certain challenges concerning the voter behaviour. The most important one is the low turnout posted in 2014. Its social, cultural, mental, and economic reasons should be both the subject to scientific research and an important issue to address by the political parties, media and NGOs that aspire to be responsible for civic education. An increase in the turnout in the future is impossible to post if the citizens do not realise the importance of the role of the European Parliament as a democratic institution in the process of counteracting the democracy deficits within the E.U. institutions. It should also translate into greater responsibility of EMPs for their activity in the European Parliament in the future.

\section{Bibliography}

CBOS [2009], Wybory do europarlamentu w powyborczych deklaracjach Polaków, Komunikat $\mathrm{z}$ badań BS/110/2009, CBOS, Warsaw.

Cybulska A. [2004], Głosujacy i niegłosujący o swoich decyzjach w wyborach do Parlamentu Europejskiego - analiza powyborcza, CBOS, Warsaw.

Czaplicki M. [2004], Pierwsze wybory europejskie w Polsce, "Analizy i Opinie", no. 25, Instytut Spraw Publicznych, Warsaw.

Doliwa-Klepacka A., Doliwa-Klepacki Z.M. [2009], Struktura organizacyjna (instytucjonalna) Unii Europejskiej, Temida 2, Bialystok.

Domagała M. [2010], Zarys organizacji i funkcjonowania Parlamentu Europejskiego, in: Wybory do Parlamentu Europejskiego w Polsce w 2009, R. Glajcar, W. Wojtasik (eds.), Remar, Katowice.

Dudkiewicz M., Fuksiewicz A., Kucharczyk J., Łada A. [2013], Parlament Europejski Społeczne zaufanie i (nie) wiedza, Instytut Spraw Publicznych, Warsaw.

EP [2011], April 28, 2011, Report on a Proposal for a Modification of the Act Concerning the Election of the Members of the European Parliament by Direct Universal Suffrage of 20 September 1976, (2009/2134 (INI)), http://www.europarl.europa.eu/sides/getDoc. do?type $=$ REPORT\&reference $=$ A7-2011-0176\&language $=E N(25.01 .2015)$. 
EP [2014a], Elections 2014: Turnout, http://www.europarl.europa.eu/elections2014-results/pl/turnout.html (16.01.2015).

EP [2014b], Results of the 2014 European Elections, http://www.europarl.europa.eu/elections2014-results/pl/election-results-2014.html (19.01.2015).

EURATOM [1957], The Treaty Establishing the European Atomic Energy Community, April 17, http://eur-lex.europa.eu/legal-content/EN/TXT/PDF/?uri=CELEX:11957A/TXT\&from= PL (24.01.2015).

EURATOM [2002], Council Decision of 25 June 2002 and 23 September 2002 Amending the Act Concerning the Election of the Representatives of the European Parliament by Direct Universal Suffrage, Annexed to Decision 76/787/ECSC, EEC, Euratom (2002/772/WE, Euratom) [1976], http://eur-lex.europa.eu/legal-content/PL/TXT/?uri=CELEX:32002D0772 (25.01.2015).

Glajcar R. [2010], System wyborczy do Parlamentu Europejskiego w Polsce, in: Wybory do Parlamentu Europejskiego w Polsce w 2009, R. Glajcar, W. Wojtasik (eds.), Remar, Katowice.

Herbut R. [2006], Wspólnota Europejska, in: A. Antoszewski, R. Herbut, Systemy polityczne współczesnej Europy, PWN, Warsaw.

Jacobs F., Corbett R., Shackleton M. [1992], The European Parliament, Longman, Harlow.

JLRP [2003], The Announcement by the State Electoral Commission, July 21, 2003, O skorygowanym wyniku ogólnokrajowego referendum w sprawie wyrażenia zgody na ratyfikacje Traktatu dotyczącego przystąpienia Rzeczypospolitej Polskiej do Unii Europejskiej, "Journal of Laws of the Republic of Poland", no. 132, item 1222 and 1223.

JLRP [2004], Ordynacja wyborcza do Parlamentu Europejskiego (the European Parliamentary Election Regulation), "Journal of Laws of the Republic of Poland", no. 25.

JLRP [2011], Kodeks wyborczy (the Electoral Code), "Journal of Laws of the Republic of Poland", no. 21.

Kandydaci SLD do Parlamentu Europejskiego (SLD Candidates to the European Parliament) [n.d.], http://www.sld.org.pl/strony/212-kandydaci_sld_do_pe.html (19.01.2015).

Łada A., Fałkowska-Warska M. [2012], Europoseł w sieci, Instytut Spraw Publicznych, Warsaw.

NP [2014], Program wyborczy Nowej Prawicy (the New Right Electoral Programme), http://www. nowaprawicajkm.pl/info/program-wyborczy/program-wyborczy-do-pe-2014/item/programwyborczy-do-pe-2014 (19.01.2015).

OBOP [2003], Polacy o członkostwie w Unii Europejskiej przed referendum, TNS OBOP, Warsaw, http://tnsglobal.pl/archiv_files/056-03.pdf (27.01.2015).

SEC [2004], The Announcement by the State Electoral Commission, June 13, http://www.pe2004. pkw.gov.pl/ (28.01.2015).

SEC [2009], The Announcement by the State Electoral Commission, June 8, http://pe2009.pkw. gov.pl/ALL/pliki/DOKUMENTY/komunikaty/obwieszczenie.pdf (30.01.2015).

SEC [2014], The Announcement by the State Electoral Commission, May 26, http://isap.sejm. gov.pl/DetailsServlet?id=WDU20140000692 (30.01.2015).

The Act Concerning the Election of the Representatives of the Assembly by Direct Universal Suffrage [1976], http://eur-lex.europa.eu/legal-content/EN/TXT/?uri=CELEX:41976D0787 (25.01.2015). 
The Treaty Establishing the European Coal and Steel Community [1951], http://eur-lex.europa. eu/legal-content/PL/TXT/?uri=CELEX:11951K/TXT (24.01.2015).

The Treaty Establishing the European Economic Community [1957], http://eur-lex.europa. eu/legal-content/PL/TXT/?uri=CELEX:11957E/TXT (24.01.2015).

Wojtasik W. [2010], Partie polityczne i system partyjny RP w wyborach do Parlamentu Europejskiego w 2009r., in: Wybory do Parlamentu Europejskiego w Polsce w 2009, R. Glajcar, W. Wojtasik (eds.), Remar, Katowice. 